NBER WORKING PAPER SERIES

\title{
COMPANY STOCK REACTIONS TO THE 2016 ELECTION SHOCK: TRUMP, TAXES AND TRADE
}

\author{
Alexander Wagner \\ Richard J. Zeckhauser \\ Alexandre Ziegler \\ Working Paper 23152 \\ http://www.nber.org/papers/w23152 \\ NATIONAL BUREAU OF ECONOMIC RESEARCH \\ 1050 Massachusetts Avenue \\ Cambridge, MA 02138 \\ February 2017
}

Wagner thanks the Swiss Finance Institute and the University of Zurich Research Priority Program Financial Market Regulation for financial support. Wagner is chairman of SWIPRA and an independent counsel for PricewaterhouseCoopers. The views expressed herein are those of the authors and do not necessarily reflect the views of the National Bureau of Economic Research.

NBER working papers are circulated for discussion and comment purposes. They have not been peer-reviewed or been subject to the review by the NBER Board of Directors that accompanies official NBER publications.

(C) 2017 by Alexander Wagner, Richard J. Zeckhauser, and Alexandre Ziegler. All rights reserved. Short sections of text, not to exceed two paragraphs, may be quoted without explicit permission provided that full credit, including $\odot$ notice, is given to the source. 
Company Stock Reactions to the 2016 Election Shock: Trump, Taxes and Trade

Alexander Wagner, Richard J. Zeckhauser, and Alexandre Ziegler

NBER Working Paper No. 23152

February 2017

JEL No. G12,G14,H25,O24

\begin{abstract}
The election of Donald J. Trump as the 45th President of the United States of America on $11 / 8 / 2016$ came as a surprise. Markets responded swiftly and decisively. This note investigates both the initial stock market reaction to the election, and the longer-term reaction through the end of 2016. We find that the individual stock price reactions to the election - that is, the market's vote - reflect investor expectations on economic growth, taxes, and trade policy. Heavy industry and banking were relative winners, whereas healthcare, medical equipment, pharmaceuticals, textiles, and apparel were among the relative losers. High-beta stocks and companies with a hitherto high tax burden benefited from the election. Although internationally-oriented companies may profit under some plans of the new administration, several other arguments suggest a more favorable climate for domestically-oriented companies. Investors have found the domesticfavoring arguments to be stronger. While investors incorporated the expected consequences of the election for US growth and tax policy into prices relatively quickly, it took them more time to digest the consequences of shifts in trade policy on firms' prospects.
\end{abstract}

Alexander Wagner

University of Zurich - Swiss Finance Institute

Department of Banking and Finance

Plattenstrasse 14

CH-8032 Zurich, Switzerland

and CEPR

alexander.wagner@bf.uzh.ch
Alexandre Ziegler

Department of Banking and Finance

University of Zurich

Plattenstrasse 14

CH-8032 Zurich

Switzerland

alexandre.ziegler@bf.uzh.ch

Richard J. Zeckhauser

John F. Kennedy School of Government

Harvard University

79 John F. Kennedy Street

Cambridge, MA 02138

and NBER

richard_zeckhauser@harvard.edu 


\section{Introduction}

The election of Donald J. Trump as the $45^{\text {th }}$ President of the United States of America on 11/8/2016 surprised most observers. The election's unexpected outcome ${ }^{1}$ combined with the wide policy differences between the two candidates caused substantial reactions on financial markets. Large price moves were recorded across asset classes, including stocks, bonds, and exchange rates. While analyst commentary on the implications of this historic election for individual firms or industries abounds, to our knowledge, no academic study has investigated which industries and firms will benefit or suffer under the new administration. Assessing the winners and losers from the election is interesting, because there were sizable differences in the policies favored by the two candidates in at least four economically important areas: government spending (and the size of the deficit), taxation, trade policy, and regulation.

This paper uses the reactions of individual stock prices during the days and weeks following the election to identify the relative winners and losers from the Trump administration's expected policies. In an era where politics is extremely polarized and forward-looking assessments of economic prospects are often tilted and exaggerated, it is instructive to investigate investors' assessment of the prospects for different firms and industries.

While there is a large literature on the effect of elections on financial markets, the 2016 Presidential election is particularly interesting because it is rare, in developed economies, to have an instance of such a surprising outcome when the two candidates favored such disparate policies. ${ }^{2}$ What is more, with the notable exception of the Mexican Peso, changes in the prices of many assets following the election were the opposite of those that had been forecast if Trump were to win. This occurred even though the forecasts had empirical support. For instance, in a study of asset price moves during the first Presidential debate on September 26, 2016, Wolfers and Zitzewitz (2016) had found a strong positive relationship between the odds of Clinton winning on Betfair and the returns on all major US equity index futures. While stock index futures fell sharply on election night as the outcome of the election became known, stock

\footnotetext{
${ }^{1}$ On the morning of Election Day, Trump's chances were $17 \%$ on Betfair and $28 \%$ on 538 Silver.

2 For example, Niederhoffer, Gibbs, and Bullock (1970) consider Dow Jones Industrial Average responses to elections and nominating conventions. Moreover, a substantial literature studies the stock market development during Democratic and Republican administrations over the longer run. For example, Santa-Clara and Valkanov (2003) document a "presidential premium" (especially for large-cap stocks) during Democratic presidencies.
} 
markets finished up on the day following the election and rallied strongly during the rest of the year.

It is impossible to determine whether the market's rally will continue beyond the time of this writing, and whether what has happened so far has been due to overall beliefs about the economy and firm fundamentals, to the view that a Trump administration will be good for business (e.g., much lower corporate taxes and reduced regulation), and/or just some combination of excess animal spirits and group exuberance. As such, the "Trump Rally" isn't that unusual: the overall market tends to rise after elections historically. What is surprising about the post-election rally is its magnitude, and its sharp difference from the significant decline that most forecasters had predicted if Trump won the election.

It is impossible to diagnose the reasons for a particular overall movement in the stock market, as there is just one observation. Recognizing this, this paper investigates the differential performance of a large number of stocks to determine which factors produced relative winners and relative losers among companies as the stock market moved sharply upward after the election. These results shed some light on the effect of expectations about policy, particularly taxation, trade policy, and regulation - on individual firms. At the industry level, the stock market reactions from the day after the election through the end of the year broadly follow expected benefits and costs relative to the alternative outcome, the election of Hillary Clinton. Heavy industry (which Trump has promised to resurrect) and financial firms, which he has said he would deregulate, performed well. By contrast, healthcare, medical equipment, and pharmaceuticals lost dramatically (presumably due to the expectation that Obamacare would be dismantled or at least significantly altered), as did textile and apparel firms, reflecting their significant dependence on imports, which Trump has vowed to strongly discourage. Business supplies and shipping containers also lost, probably reflecting his tough stance on trade. It is noteworthy that even after controlling for the rally in the broad market, several low-beta industries (beer, tobacco, food products, utilities) were losers, while cyclical industries tended to be winners. Presumably, expectations of higher growth induced investors to rotate from low-risk to high-beta industries.

All assessments of industries or companies below address relative not absolute assessments, since the stock market was up so dramatically, implying that many relative losers actually gained in price, but not nearly so much as relative winners. Turning to the different policy areas, we find 
evidence that both growth prospects and expectations of a major corporate tax cut were viewed positively by the stock market. By contrast, the stock market's reactions imply negative expectations about the effects of the incoming administration's anticipated policies for internationally-oriented firms. Interestingly, markets did not process information on these various aspects at the same speed. While the positive impacts of corporate tax cuts and higher growth were apparent in the cross-section of stock returns on the first day after the election, the negative impact of expected policy changes on internationally-oriented firms mostly became felt later on. Investors also downgraded companies with high interest expenses. This result does not necessarily have to do with an expectation regarding interest deductibility being abolished (as is the case under some Trump/Republican plans), as deductions also lose value when taxes are cut. Investors thus far think that expensing capital investments is either unlikely to be implemented, or not consequential.

\section{Asset price responses to news}

If the market responds optimally to the election outcome, the change in the market price of any asset will reflect both the difference in its expected discounted payoff between the two possible outcomes and the ex ante probability of the outcome. The advantage of considering asset price changes is that they capture current expectations; the researcher need not trace all the future changes to cash flows and discount rates separately (Schwert 1981). Formally, let $P_{C}$ and $P_{T}$ denote the asset's expected price conditional on Clinton and Trump winning, respectively, implying that $\pi_{C}$ and $\pi_{T}=1-\pi_{C}$ are the probabilities of the two outcomes. Ignoring discounting over the short period at hand, and assuming that risk aversion is a minor factor, ${ }^{3}$ the asset's price before the election is given by

$$
P=\pi_{C} P_{C}+\pi_{T} P_{T}
$$

The price change for the asset given that Trump won is given by

$$
\Delta P=P_{T}-P=\left(P_{T}-P_{C}\right)\left(1-\pi_{T}\right) .
$$

\footnotetext{
${ }^{3}$ Risk aversion on overall market movements would, of course, be reflected in beta. Stocks expected to perform better in an unfavorable overall outcome would be priced higher and vice versa.
} 
In words, the price change once the election results become known is the difference in prices between the two outcomes, times the size of the election surprise, which is one minus the ex ante probability of Trump winning. Intuitively, if Trump's election had been certain ex ante, there would have not have been a price reaction on the day after the election. Scaling this expression by the initial price, the return on the asset once the election results become known is given by

$$
R=\frac{P_{T}-P}{P}=\frac{\left(P_{T}-P_{C}\right)\left(1-\pi_{T}\right)}{P} .
$$

Note that while the election surprise is the same for all assets, individual assets will respond to the election outcome differently, depending on the sign and magnitude of the spread between $P_{C}$ and $P_{T}$. For assets that would have benefitted from a Clinton outcome relative to Trump, $P_{C}>$ $P_{T}$, with the inequality reversed for assets that would be helped by a Trump outcome. To presage some of our findings, stocks had very different reactions to the outcome. By considering the cross-section of stock returns, we can thus infer whether the incoming administration's expected policies are viewed as favorable or not for a particular firm or industry, and the extent and speed with which markets incorporated differences between the candidates in the different policy dimensions into prices.

Two factors make the 2016 Presidential election an ideal setting for such an analysis. First, there was a significant gap between the pre-election probabilities and the election outcome. Clinton was the clear favorite on betting markets, in polls, and on election-modeling websites. For instance, on November 7, the probability of Clinton winning on Betfair was $83 \%$, while on the day of the election, even the FiveThirtyEight forecast, which was the major site that gave Trump the highest probability of winning, put the Clinton odds between $71 \%$ and $72 \%$. Second, there were major differences between the policies favored by the two candidates. This combination explains why the asset price reactions on numerous markets, from stock indices to bonds to exchange rates, were so strong.

While the election outcome did reduce uncertainty about firms' prospects, it hardly rendered those uncertainties modest for a number of reasons. First, the elected candidate is expected to backtrack on some pledges made on the campaign trail, even some made repeatedly, or change his mind on intended policies or the strength with which he will pursue them. Second, many policies need Congressional approval. Although the Republicans currently control Congress, 
their majority in the Senate is merely two, and a number of Republican senators dislike Trump and/or some of his policies. Thus, he may push policies, but Congress may not approve. Accordingly, the specific design and perceived probabilities of various policies being implemented remained subject to large shifts even after the election results were known. Thus, sizable relative asset-price reactions could be expected in the weeks that followed.

Though our focus is on individual companies and industries, it is important to note the dramatic stock market development since Trump's election became known. The overall stock market, as represented by the S\&P 500, marched upward by $4.64 \%$ to year-end, and a further $1.45 \%$ through the Inauguration on January 20, 2017. This development is noteworthy for multiple reasons. First, prior to the election, it was broadly felt that the stock market would fall significantly if Trump were elected. Wolfers and Zitzewitz (2016) investigate the reaction of a number of asset prices during the first Presidential debate on September 26, 2016. They find a strong positive relationship between the odds of Clinton winning from Betfair and the returns on all major US equity index futures. During the debate, which lasted from 9 to 11 p.m., the odds of Clinton winning rose from 63 to $69 \%$, and S\&P 500 futures by $0.71 \%$, implying a S\&P 500 value about $12 \%$ higher under Clinton than under Trump. On the day following the election, Bank of America Merrill Lynch cut its forecasts for US GDP growth by half a percentage points in both the first and second quarters of 2017, and warned of "despair in the financial markets". Second, there were no significant surprises about economic prospects, or President-elect Trump's plans during this period. Third, the sustained surge was conceivably a reaction to both the election results and the surprising favorable market movement immediately following the election. If so, it would represent a dramatic form of Post Information-Revelation Drift. Alternatively, it might just represent the common phenomenon of the market having a sustained movement up or down, despite little new information being revealed.

\section{Data and empirical strategy}

The surprising election outcome provides an ideal setting for an event study. Our empirical strategy, therefore, is to regress abnormal returns (ARs) on firm characteristics. Since markets may need time to digest new information, and further information on the incoming administration's proposed policies became clearer only after the election, we consider different sets of abnormal returns: those from the day after the election through to the end of 2016, those 
on the day after the election, and the drift from two days after the election to the end of 2016. This allows us to shed light on both the overall reaction and the speed with which the market reacted. We note that the end of 2016 is a somewhat arbitrary end point. (In the text, we refer to December 31, 2016 as the end of the year, though December 30, 2016 was the last trading day.)

Our sample includes the S\&P 500 constituents as of the day of the election. ${ }^{4}$ The S\&P 500 index includes the largest, most liquid U.S. stocks; they get the greatest analyst coverage and the strongest investor attention. Together, the index constituents represent roughly $80 \%$ of the U.S. equity market capitalization.

We obtain stock prices adjusted for splits and net dividends from Bloomberg. We then compute each stock's market beta from an OLS regression of daily stock returns in excess of the risk-free rate on the excess returns on the S\&P 500 total return index for the period from September 30, 2015 to September 30, 2016 (estimation window). ${ }^{5}$ The risk-free rate is the onemonth T-bill rate. ${ }^{6}$ We then compute abnormal returns for all days surrounding the November 8 , 2016 election as the daily excess return on the stock minus beta times the S\&P 500 excess return. Although stock returns are driven by common factors beyond moves in the broad market - the most examined factors being size, value, and momentum - we choose to correct only for market moves in our analysis because the election outcome is likely to have caused shifts in these factors as well. Controlling for them would therefore eliminate part of the effects that we wish to document.

Figure 1 plots some quantiles of the distributions of the returns in the election week and in the November 9 to December 31 time window, and indicates substantial heterogeneity in firms' reactions. It is noteworthy (though not surprising) that the spreads of the abnormal returns after the election greatly exceed those before.

\footnotetext{
4 The exact date chosen is not critical since there were no changes in the composition of the index between September 30, 2016 and December 2, 2016, and only a single change through December 31.

${ }^{5}$ Data are available for the entire estimation window for 493 out of the 500 firms. The seven other firms have a short return history because they result from spin-offs and met the index inclusion criteria soon after their first trade date. An example is Hewlett Packard Enterprise Company, which was spun off from HP Inc. on 11/02/2015 and entered the S\&P 500 index on that same date. Beta for these firms is estimated using returns from the date the firm was first traded to September 30, 2016.

${ }^{6}$ The results are virtually identical if we use the returns on the S\&P 500 price index instead of those on the total return index and/or the Fed funds rate instead of the T-bill rate.
} 


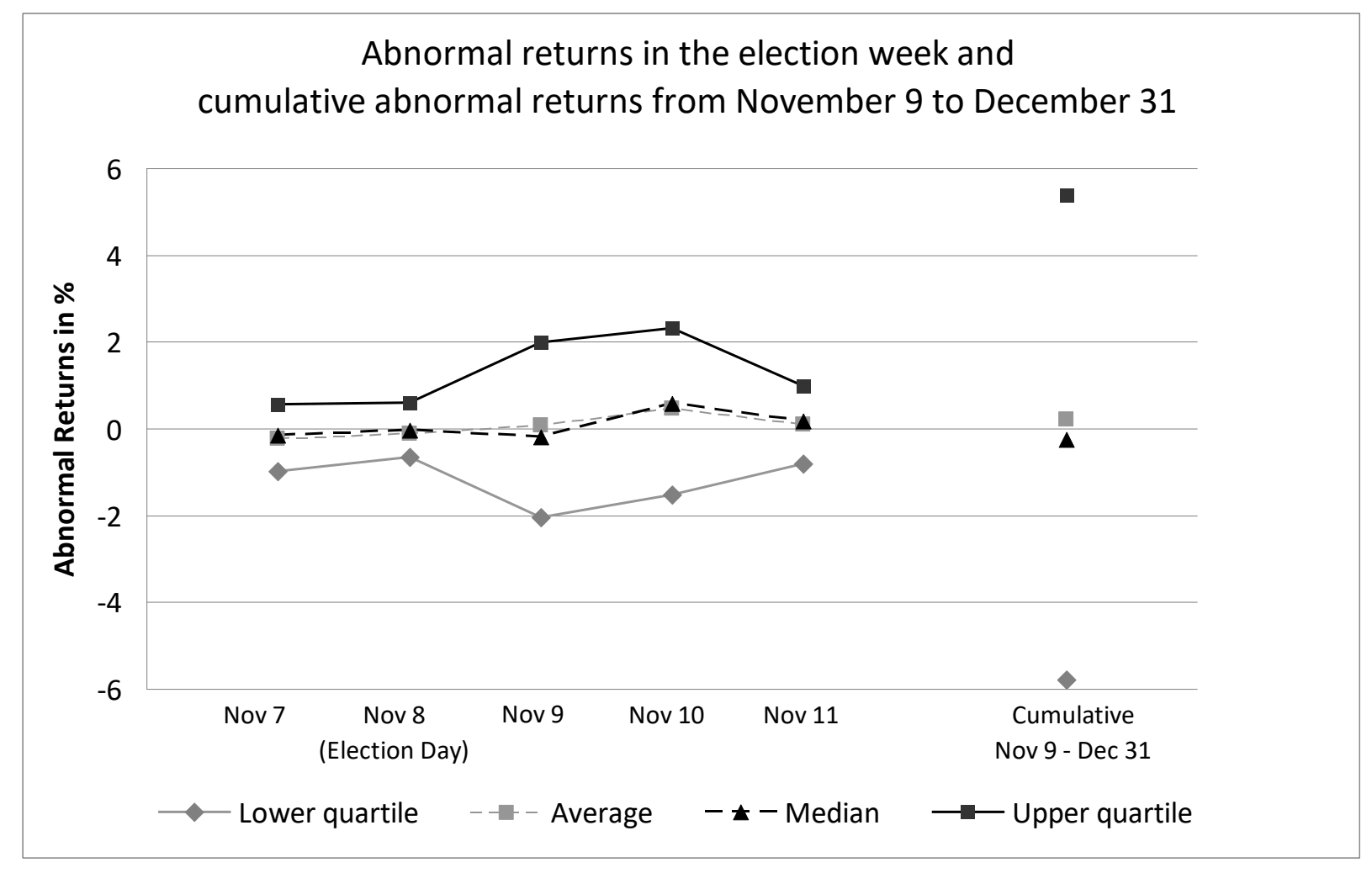

Figure 1: Abnormal stock returns in the election week and beyond

This figure shows the abnormal returns in each of the 5 days of the election week as well as the cumulative abnormal return from November 9 (one day after the election) to December 31, 2016

We obtain explanatory variables mostly from Compustat Capital IQ. We use the most current accounting data for all companies. For most companies, this means we use December 31, 2015 data. Several companies have fiscal years that end in other months. Thus, we have 79 companies for which calendar year 2016 data are included. ${ }^{7}$ The cash effective tax rate (cash ETR) is computed following Dyreng, Hanlon, Maydew, and Thornock (2017) as the percent cash taxes paid relative to current year pretax income. ${ }^{8}$ As an alternative proxy for the tax rate, we use the disclosed effective tax rate (which uses tax expenses, instead of cash taxes paid), collected from the tax footnotes of 10-K statements by Audit Analytics. We obtain the percentage of firm revenue from foreign sources from Bloomberg, and we supplement these data with information from Compustat geographical segment data. As a proxy for production costs incurred abroad,

\footnotetext{
${ }^{7}$ Even among the companies with December 31 as fiscal year end, there are already a few companies in Compustat with year-end 2016 data. It is in principle conceivable that they adjusted their accounting after the election, but a robustness check reveals that using year-end 2015 data yields similar results.

${ }^{8}$ As in their study, when using this variable, we restrict the sample to those firms with positive pre-tax income (all but 43 companies) as well as a tax rate below 100\% (all but 3 companies).
} 
we compute the percentage of non-US assets in total assets from Compustat geographical segment data. As for many companies, this variable is not yet available for 2016; we use data for the years 2013, 2014, and 2015. There are some missing data on foreign revenues, foreign assets, and/or foreign profits. From Audit Analytics, we obtain data for indefinitely reinvested foreign earnings as of May 2016, and we divide this number by total assets to obtain our proxy for cash held abroad. All other variables are standard. Table 1 provides the details of the computation.. All explanatory variables (except market cap) are winsorized at the $1 \%$ and $99 \%$ levels.

\section{Table 1: Descriptive statistics}

Our sample includes the S\&P 500 constituents as of November 8, 2016. Abnormal returns for all days from November 9, 2016 to December 31, 2016 are computed as the daily excess return on the stock minus beta times the S\&P 500 excess return, where beta is estimated on daily excess returns from September 30, 2015 to September 30, 2016. The risk-free rate is the 1-month T-bill rate. The following variables are from Compustat or computed based on Compustat data (Compustat mnemonics in capitals in parentheses): Total Assets (AT), Market value of equity (CSHO*PRCC_F), Percent revenue growth (100*(SALE-SALEt-1)/SALEt-1, Profitability $(100 *$ pretax income $/$ assets $=100 *(\mathrm{PI} / \mathrm{AT}))$, Cash taxes paid in percent of current year pretax income $(100 *(\mathrm{TXPD} / \mathrm{PI}))$, Percent profits from foreign activities (100*PIFO/PI), Foreign operations in percent of assets $(100 * \mathrm{abs}(\mathrm{PIFO}) / \mathrm{AT})$, Leverage (DLTT+DLC)/AT, Interest expenses in percent of assets $(100 * \mathrm{XINT} / \mathrm{AT})$, Capital expenditures in percent of assets $(100 * \mathrm{CAPX} / \mathrm{AT})$. The sources of additional variables are as follows: The disclosed effective tax rate in percent and Indefinitely reinvested foreign earnings (which we divide by AT) are obtained from Audit Analytics. Percent revenue from foreign sources is from Bloomberg, supplemented by data computed from Compustat segments data. Percent foreign assets is computed from Compustat segments data. Dividend yield is from Bloomberg.

Cumulative abnormal return from Nov 9 to Dec 31, 2016 Abnormal return on Nov 9 ( 1 day after election)

Cumulative abnormal return from Nov 10 to Dec 31, 2016

Total assets (US\$ millions)

Market value of equity (US\$ millions)

Beta

Percent revenue growth

Profitability

Cash taxes paid in percent of pretax income

Disclosed effective tax rate in percent

Percent revenue from foreign sources

Percent foreign assets

Percent profits from foreign activities

Foreign operations in percent of assets

Indefinitely reinvested foreign earnings in percent of assets

Dividend yield

Leverage

Interest expenses in percent of assets

Capital expenditures in percent of assets

\begin{tabular}{rrrrrrrr} 
Obs & \multicolumn{1}{c}{ Min } & P25 & Mean & Median & P75 & Max & Std. Dev. \\
500 & -30.66 & -5.79 & 0.21 & -0.25 & 5.38 & 41.50 & 8.93 \\
500 & -20.32 & -2.04 & 0.08 & -0.18 & 1.99 & 15.26 & 3.71 \\
500 & -26.09 & -4.62 & 0.10 & 0.26 & 4.60 & 45.97 & 7.85 \\
500 & $1^{\prime} 703$ & $7^{\prime} 793$ & $64^{\prime} 066$ & $17^{\prime} 457$ & $45^{\prime} 315$ & $2^{\prime} 490^{\prime} 972$ & $205^{\prime} 721$ \\
500 & $2^{\prime} 684$ & $9^{\prime} 837$ & $38^{\prime} 174$ & $17^{\prime} 788$ & $36^{\prime} 893$ & $603^{\prime} 254$ & $63^{\prime} 088$ \\
500 & 0.15 & 0.84 & 1.09 & 1.05 & 1.32 & 2.85 & 0.41 \\
500 & -49.15 & -5.97 & 0.11 & 0.93 & 7.05 & 50.95 & 16.31 \\
500 & -72.08 & 3.06 & 7.06 & 6.90 & 12.33 & 33.61 & 12.32 \\
434 & -2.00 & 14.08 & 23.75 & 24.21 & 32.86 & 70.87 & 14.82 \\
458 & 0.00 & 22.00 & 28.42 & 30.00 & 35.00 & 80.00 & 11.71 \\
406 & 0.00 & 13.63 & 36.31 & 36.81 & 54.68 & 100.00 & 26.53 \\
210 & 0.00 & 19.40 & 37.24 & 31.65 & 50.97 & 100.00 & 26.52 \\
350 & -167.74 & 10.46 & 43.20 & 37.90 & 71.33 & 272.43 & 56.21 \\
350 & 0.00 & 0.95 & 4.33 & 3.09 & 6.16 & 21.92 & 4.35 \\
323 & 0.00 & 0.03 & 0.21 & 0.13 & 0.35 & 1.19 & 0.21 \\
500 & 0.00 & 0.75 & 2.07 & 1.95 & 2.90 & 20.47 & 1.93 \\
500 & 0.00 & 0.18 & 0.31 & 0.29 & 0.42 & 0.86 & 0.18 \\
470 & 0.00 & 0.64 & 1.25 & 1.11 & 1.68 & 5.08 & 0.86 \\
490 & 0.00 & 1.06 & 4.10 & 2.71 & 5.58 & 22.17 & 4.43
\end{tabular}




\section{Stock return reactions to Trump's election at the industry level}

The most salient feature of reactions of individual stocks to the election - covered also in the popular press by way of anecdotal evidence, and not controlling for risk - is that President Trump's statements about specific industries or groups of industries produced large gains or losses at the industry level. His promises to deregulate and to discourage imports are, not surprisingly, strongly reflected in the data. However, as we demonstrate below, initial stock-price reactions (a) reversed for some industries, and/or (b) did not capture the magnitude of stock price changes until the end of the year. Presumably, market participants were both digesting the election and responding to new data available from post-election statements by President-elect Trump, as well as some from Congress.

Figure 2 plots median abnormal returns in the Fama-French 30 industries between the market close on November 8 - before the election results were known - and the end of 2016 (light grey), as well as those on the day following the election (dark grey). ${ }^{9}$ Adjusting for the market's overall move, the number of (relative) winners and loser industries is roughly balanced. The returns for the overall period are in line with what one would expect based on Trump's statements on the campaign trail: heavy industry (which Trump has promised to resurrect) and financial firms, which he has said he would deregulate, were perceived to benefit from Trump's election. Healthcare, medical equipment, and pharmaceuticals lost dramatically (a consequence of the expectation that Obamacare would be dismantled or at least significantly altered), as did textile and apparel firms, reflecting their large dependence on imports, which Trump has vowed to strongly discourage. Business supplies and shipping containers also lost, probably reflecting his tough stance on trade.

It is noteworthy that several low-beta industries (beer, tobacco, food products, utilities) are among the losers, while cyclical industries tend to be among the winners. Presumably, expectations of higher growth induced investors to rotate from low-risk to high-beta industries. In a low-growth, low-interest rate environment like the one prevailing in recent years, investors had been piling into low-beta industries to earn the high dividend yields that they often offer. As Trump's election also led to a notable rise in long-term interest rates, stock prices in these industries suffered.

\footnotetext{
${ }^{9}$ We use medians to avoid the impact of outliers in this detailed industry classification. The picture with average returns looks very similar. When using Fama-French 17 industries we also obtain the result that steel works, mining, and drugs benefited most significantly.
} 


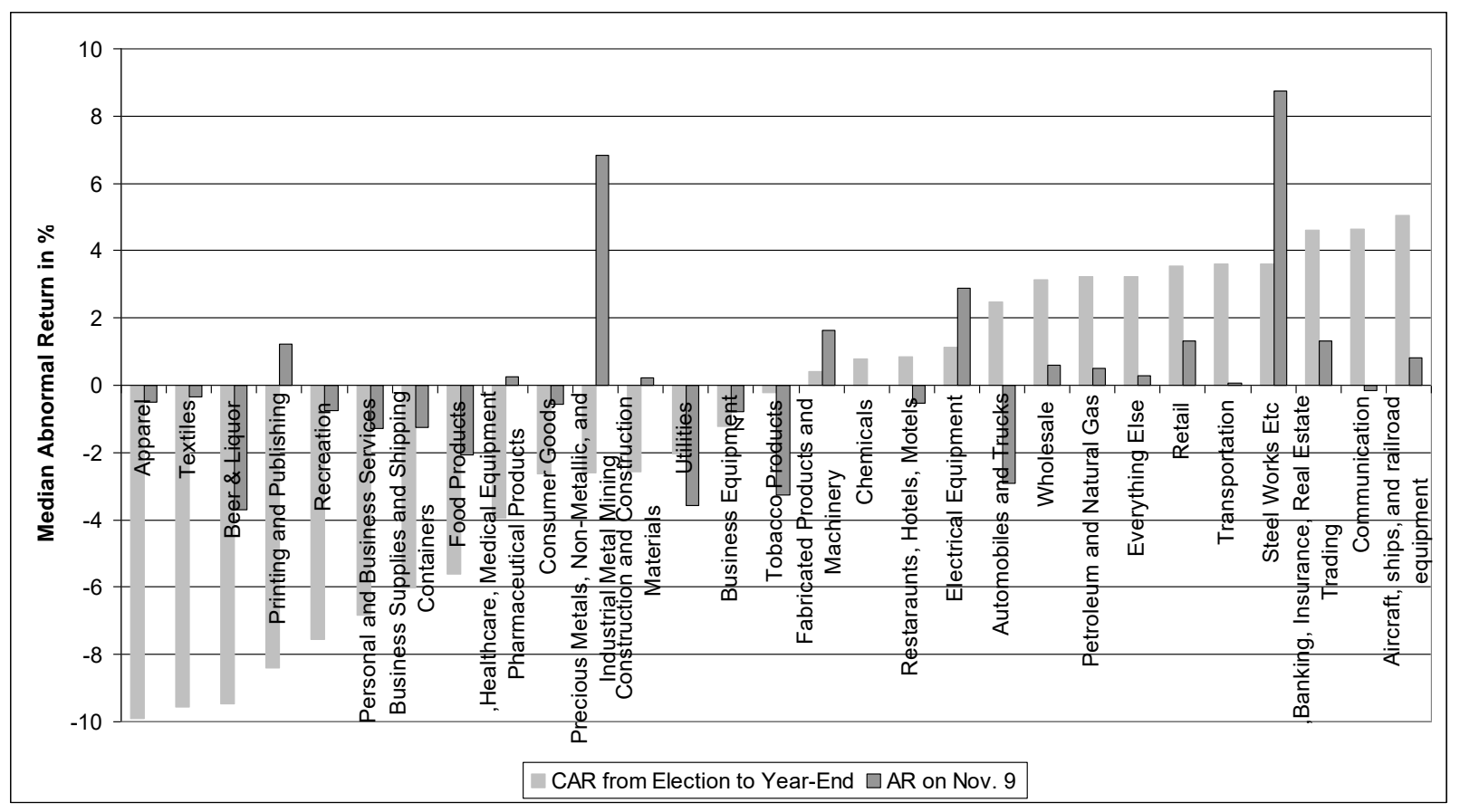

Figure 2: Median abnormal returns after the election by Fama-French 30 industries

The results in Figure 2 also reveal that the cumulative abnormal returns from the election to year-end differ substantially from the immediate response after the election, shown in dark grey in the figure. Apparel and textiles, which are the worst performers during the overall period, only had a modest drop on the day after the election. A similar pattern holds for medical equipment and medical products: the immediate reaction to Trump's election was one of relief and indeed a light increase, as markets were seriously worried about Hillary Clinton's critical stance on drug prices. However, concerns about the industry's profitability escalated when Trump started making critical statements about pharmaceutical products' prices after the election. ${ }^{10}$ At the other end of the spectrum, markets seem to have been initially too optimistic about the prospects for the steel industry (which had been one of the hot spots of the campaign), and barely reacted at the outset to the prospect of deregulation in the financial industry. Another interesting case is the automobile industry, which suffered initially (probably reflecting fears of Trump's meddling in

\footnotetext{
${ }^{10}$ Considering the abnormal returns using the Fama-French 48 industries, in which healthcare and pharmaceuticals constitute two different industries, provides support for this interpretation. In this case, the abnormal returns on the day after the election are $+5.02 \%$ for pharmaceuticals and $-4.71 \%$ for healthcare, while the cumulative abnormal returns from the election to the end of the year are $-3.95 \%$ for pharmaceuticals and $-2.34 \%$ for healthcare.
} 
plant location decisions), but had become one of the top performers by year-end (probably reflecting expectations of higher profits due to tariffs on imports).

Thus, while the initial strongly positive response of the overall stock and bond market to the election outcome persisted through the rest of the year, there was no continuation of industrylevel abnormal returns, quite the opposite. As can be seen in Figure 3, the relationship between the abnormal returns on November 9 and those between November 10 and year-end at the industry level is actually negative (the correlation is -0.25 ).

This finding has two potential explanations. The first is that investors overreacted to the initial news. What speaks against this interpretation is that at the overall market level - both for stocks and bonds yields - the response on the day following the election continued into year-end (and indeed through the Inauguration on January 20, 2017). Thus, for the observed phenomenon to arise, one would need investors to overreact about the prospects for some industries and underreact about the prospects for others, an unlikely parlay. The second, and more plausible, explanation is that the market's assessment about the strength and/or likelihood of some of the incoming administration's future policies changed after the election or took more time to be incorporated into prices because processing the information on these policies was more difficult. What speaks in favor of this latter interpretation are the strong negative returns until the end of the year in import-intensive and trade-sensitive industries (textile, shipping containers), and the positive returns in industries that would benefit from trade restrictions (automobiles) or proposed deregulation (banking).

While these descriptive industry-level results reveal large differences in the asset price response across industries, heterogeneity across firms within the same industry is typically as large as that across industries, both in terms of abnormal returns and firm characteristics. Below, we capitalize on firm-level heterogeneity in order to assess the impact of different prospective policy developments. Since our analysis reveals large differences between the immediate response to the election and that until year-end, we investigate these responses separately. 


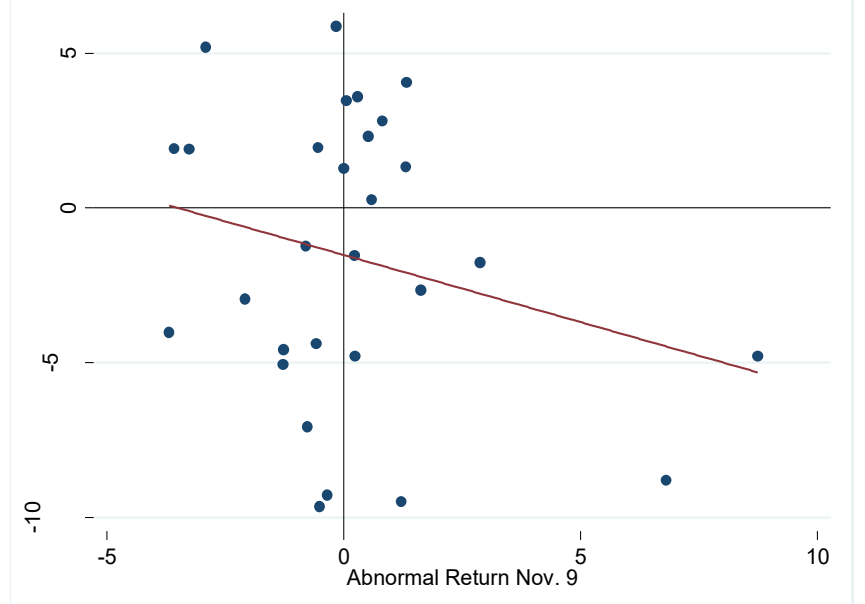

Figure 3: Relationship between median abnormal returns on November 9, 2016 and from November 10 to year-end 2016 by Fama-French 30 industries

\section{Explaining the cross-section of stock return reactions}

This section investigates the cross-section of stock price responses to the election outcome. It examines the impact of expectations about overall growth, taxation, and trade policy.

\subsection{Growth expectations}

If the market believes that Trump is good for the aggregate economy, those companies that are more strongly exposed to the (US) economy will do better. To have a first look at this hypothesis, Figure 4 presents a binned scatter plot. That is, all stocks are sorted into 20 equalsized bins by their market beta, and we then compute the average abnormal stock return in each of the bins.

A positive relationship emerges. Clearly, investors flocked to high-beta equities after the election. This result adds to the insights of Figure 2. There, we had seen that many of the worst performing industries were low-beta industries. However, note that Figure 4 shows results controlling not only for market beta (via the abnormal return computation), but also for industry fixed effects. 

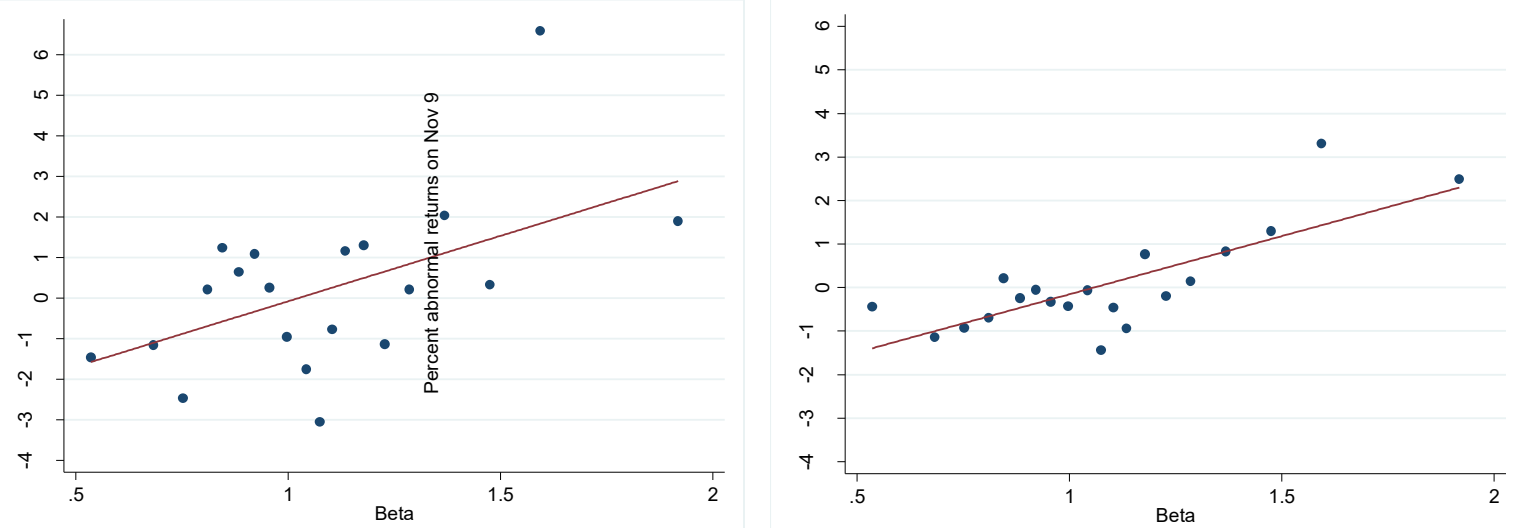

Figure 4: Binned scatter plots of Beta against abnormal returns from November 9 to December 31, 2016 (left panel) and abnormal returns on November 9, 2016 (right panel) (controlling for Fama-French 30 industries fixed effects)

Table 2 presents the corresponding regression output, documenting strong statistical significance of the positive market reaction of high-beta stocks. Strikingly, almost all of this reaction took place on the first day, while beta does not significantly predict abnormal returns into year-end. While we do not report the coefficients on the industry dummies for space reasons, this regression analysis shows that the industry fixed effects that are significant without controlling for beta remain significant (with one exception) even when controlling for beta. This suggests that some industries were expected to benefit over and above what the aggregate economy does, even after adjusting for their average cyclicality.

Table 2 also reveals that size does not seem to matter directly for firms' stock market performance. Profitability itself does not explain abnormal returns either. Thus, the market does not seem to believe that CEO Trump would "fire" weakly performing firms. It is somewhat puzzling that faster-growing firms (those with higher revenue growth) have reacted less positively, even after controlling for industry. One might have thought that investors would see an improved future for these companies given the Trump victory. Conceivably, investors are worried that these firms, which rely on a stable environment to make their long-term growth plans, will find themselves in a less predictable economic and regulatory setting. We do not, however, have a conclusive explanation for this finding. 
Table 2: Cyclicality, growth, and industries

This table presents OLS regressions of the abnormal returns from November 9, 2016 to December 31, 2016 (columns (1) to (3)), on November 9, 2016 (column (4)), and from November 10, 2016 to December 31, 2016 (column (5)) on firm characteristics and Fama-French 30 industry fixed effects. T-statistics based on robust standard errors are shown in parentheses. $* * * \mathrm{p}<0.01, * * \mathrm{p}<0.05, * \mathrm{p}<0.1$

\begin{tabular}{|c|c|c|c|c|c|}
\hline \multirow[b]{2}{*}{ Dependent variable: } & (1) & $(2)$ & (3) & (4) & $\begin{array}{c}\text { (5) } \\
\text { CAR } 10\end{array}$ \\
\hline & \multicolumn{3}{|c|}{ CAR Nov 9 to Dec 31} & AR Nov 9 & to Dec 31 \\
\hline \multirow[t]{2}{*}{ Ln(Market value of equity) } & -0.051 & 0.038 & -0.158 & 0.219 & -0.368 \\
\hline & $(-0.13)$ & $(0.10)$ & $(-0.41)$ & $(1.47)$ & $(-1.09)$ \\
\hline \multirow[t]{2}{*}{ Beta } & $4.106^{* * *}$ & $3.193 * * *$ & $2.925 * *$ & $2.624 * * *$ & 0.264 \\
\hline & $(4.05)$ & $(2.92)$ & $(2.27)$ & (4.95) & $(0.23)$ \\
\hline \multirow[t]{2}{*}{ Percent revenue growth } & & $-0.068 * * *$ & $-0.080 * * *$ & $-0.031 * *$ & $-0.047 * *$ \\
\hline & & $(-2.91)$ & $(-3.02)$ & $(-2.06)$ & $(-1.98)$ \\
\hline \multirow[t]{2}{*}{ Profitability } & & -0.026 & 0.007 & -0.006 & 0.013 \\
\hline & & $(-0.78)$ & (0.19) & $(-0.42)$ & $(0.38)$ \\
\hline \multirow[t]{2}{*}{ Constant } & -3.758 & -3.454 & $-11.559 * * *$ & $-4.622 * * *$ & $-6.844 * *$ \\
\hline & $(-0.90)$ & $(-0.85)$ & $(-2.99)$ & $(-2.96)$ & $(-2.04)$ \\
\hline Industry fixed effects & no & no & yes & yes & yes \\
\hline Observations & 500 & 500 & 500 & 500 & 500 \\
\hline R-squared & 0.035 & 0.053 & 0.235 & 0.273 & 0.227 \\
\hline
\end{tabular}

\subsection{Corporate tax rates}

While the details of any future tax plan remain somewhat hazy, it is clear that President Trump wants to cut corporate taxes significantly below their current $35 \%$ level, and is very likely to succeed, given that the Republican majority in Congress, as well as many Democratic legislators, have the same preference. Had Hillary Clinton won the election, corporate taxes might well have been trimmed, but not cut nearly to the level that Trump has proposed, namely $15 \%$. (President Obama had supported a cut to $28 \%$.)

Given the surprisingly large expected reduction in corporate taxes due to Trump's election, we would expect those companies currently paying higher taxes to perform better. At first sight, Column (1) of Table 3 appears to suggest only a modest (and statistically insignificant) relationship between the cash effective tax rate and the cumulative abnormal returns from November 9, 2016 to December 31, 2016. Here, one needs to keep in mind that long-term returns are notoriously difficult to predict and noisy. However, as can be seen in 
Column (2), there was actually a strong market response to differences in taxation across firms, but it took place swiftly on the first day after the election. Economically, this effect is sizable: In this sample, the standard deviation of the cash effective tax rate is 15.4. Therefore, a one standard deviation higher effective tax rate is associated with a 0.41 percentage point $(15.4 * 0.032)$ increase in the abnormal return on the day after the election, more than $10 \%$ of a standard deviation of the abnormal returns. A substantial portion of the overall reaction was, therefore, already impounded in stock prices on the first day. Tables available on request show that controlling for special items does not affect the results. ${ }^{11}$

Columns (4) to (6) use the disclosed effective tax rate instead of the cash ETR. This item, reported in the tax footnotes to $10-\mathrm{K}$ statements of most, though not all companies, captures the total tax expenses (rather than the cash taxes) that a company records. We again find a more positive investor reaction for those firms with a higher tax burden according to this measure. Interestingly, although the relationship between taxes and abnormal returns proved strongly positive in the first day after the election, it remained large and significant in the period running into year-end. This suggests that the market needed more time to incorporate information reported in the footnotes to $10-\mathrm{K}$ statements than information available from financial statements.

In sum, these results show not only that the market reacted in the expected way to Trump's election, but this relatively clean natural experiment also confirms that taxes are a very important component of firm value. Figure 5 illustrates this result in binned scatter plots.

\footnotetext{
${ }^{11}$ As a measure of the level of a firm's tax sheltering, we also compute the book tax gap following Manzon and Plesko (2002) and Jalan, Kale and Meneghetti (2016). This captures the difference between the income a firm reports to its shareholders based on GAAP and the one it reports to the income tax authorities based on tax laws. The latter is not observable. Following the literature, we compute [PI-PIFO-TXFED/0.35] - TXS - TXO - ESUBC. The part in the square brackets is the "unadjusted spread". The three items subtracted at the end (state income taxes, other income taxes, unremitted earnings in non-consolidated subsidiaries) can affect the gap for reasons unrelated to tax sheltering. Dividing the total quantity of the above calculation by total assets yields the book tax gap. We do not find a significant association of this proxy for tax sheltering and announcement returns. However, the sample in this is quite small (around 200 observations) due to missing data (which, according to Manzon and Plesko (2002), should not be treated as zero entries in these cases).
} 


\section{Table 3: Corporate tax rates}

This table presents OLS regressions of the abnormal returns from November 9, 2016 to December 31, 2016 (columns (1) and (4)), on November 9, 2016 (columns (2) and (5)), and from November 10, 2016 to December 31, 2016 (columns (3) and (6)) on firm characteristics and Fama-French 30 industry fixed effects. Data for cash taxes paid and/or the disclosed effective tax rate is missing for some companies. The sample in regressions (1) to (3) includes S\&P 500 firms with a cash effective tax rate below $100 \%$ and with positive pre-tax income. The sample in regressions (4) to (6) includes firms with a disclosed effective tax rate below $100 \%$. T-statistics based on robust standard errors are shown in parentheses. ${ }^{* * *} \mathrm{p}<0.01,{ }^{* *} \mathrm{p}<0.05, * \mathrm{p}<0.1$

\begin{tabular}{|c|c|c|c|c|c|c|}
\hline Dependent variable: & $\begin{array}{c}\text { (1) } \\
\text { CAR Nov } 9 \text { to } \\
\text { Dec } 31\end{array}$ & $\begin{array}{c}\text { (2) } \\
\text { AR Nov } 9 \\
\end{array}$ & $\begin{array}{c}\text { (3) } \\
\text { CAR Nov } 10 \\
\text { to Dec } 31\end{array}$ & $\begin{array}{c}\text { (4) } \\
\text { CAR Nov } 9 \text { to } \\
\text { Dec } 31\end{array}$ & $\begin{array}{c}\text { (5) } \\
\text { AR Nov } 9\end{array}$ & $\begin{array}{c}\text { (6) } \\
\text { CAR Nov } 10 \\
\text { to Dec } 31\end{array}$ \\
\hline Cash taxes paid in percent of pretax income & $\begin{array}{l}0.042 \\
(1.12)\end{array}$ & $\begin{array}{c}0.032^{* *} \\
(2.13)\end{array}$ & $\begin{array}{l}0.011 \\
(0.34)\end{array}$ & & & \\
\hline Disclosed effective tax rate & & & & $\begin{array}{c}0.135^{* * *} \\
(4.13)\end{array}$ & $\begin{array}{c}0.054^{* * *} \\
(2.92)\end{array}$ & $\begin{array}{c}0.079 * * * \\
(2.86)\end{array}$ \\
\hline $\operatorname{Ln}($ Market cap) & $\begin{array}{l}-0.270 \\
(-0.63)\end{array}$ & $\begin{array}{l}0.282^{*} \\
(1.73)\end{array}$ & $\begin{array}{l}-0.536 \\
(-1.44)\end{array}$ & $\begin{array}{l}-0.300 \\
(-0.73)\end{array}$ & $\begin{array}{l}0.209 \\
(1.30)\end{array}$ & $\begin{array}{l}-0.490 \\
(-1.40)\end{array}$ \\
\hline Beta & $\begin{array}{c}3.228^{* *} \\
(2.28)\end{array}$ & $\begin{array}{c}2.979 * * * \\
(4.73)\end{array}$ & $\begin{array}{l}0.197 \\
(0.15)\end{array}$ & $\begin{array}{l}2.630^{*} \\
(1.94)\end{array}$ & $\begin{array}{c}2.456 * * * \\
(4.59)\end{array}$ & $\begin{array}{l}0.145 \\
(0.12)\end{array}$ \\
\hline Percent revenue growth & $\begin{array}{c}-0.078^{* *} \\
(-2.54)\end{array}$ & $\begin{array}{c}-0.047^{* * *} \\
(-2.66)\end{array}$ & $\begin{array}{l}-0.031 \\
(-1.19)\end{array}$ & $\begin{array}{c}-0.086 * * * \\
(-2.90)\end{array}$ & $\begin{array}{c}-0.035^{* *} \\
(-2.03)\end{array}$ & $\begin{array}{c}-0.049^{*} \\
(-1.85)\end{array}$ \\
\hline Profitability & $\begin{array}{l}-0.076 \\
(-1.12)\end{array}$ & $\begin{array}{l}-0.007 \\
(-0.28)\end{array}$ & $\begin{array}{l}-0.065 \\
(-1.10)\end{array}$ & $\begin{array}{l}-0.015 \\
(-0.37)\end{array}$ & $\begin{array}{l}-0.014 \\
(-0.94)\end{array}$ & $\begin{array}{l}-0.001 \\
(-0.04)\end{array}$ \\
\hline Constant & $\begin{array}{l}-0.763 \\
(-0.17)\end{array}$ & $\begin{array}{c}-6.519 * * * \\
(-3.58)\end{array}$ & $\begin{array}{l}5.565 \\
(1.40)\end{array}$ & $\begin{array}{l}-3.176 \\
(-0.72)\end{array}$ & $\begin{array}{c}-6.019 * * * \\
(-3.37)\end{array}$ & $\begin{array}{l}2.699 \\
(0.71)\end{array}$ \\
\hline Industry FE & Yes & Yes & Yes & Yes & Yes & Yes \\
\hline Observations & 434 & 434 & 434 & 458 & 458 & 458 \\
\hline R-squared & 0.228 & 0.298 & 0.211 & 0.262 & 0.294 & 0.226 \\
\hline
\end{tabular}



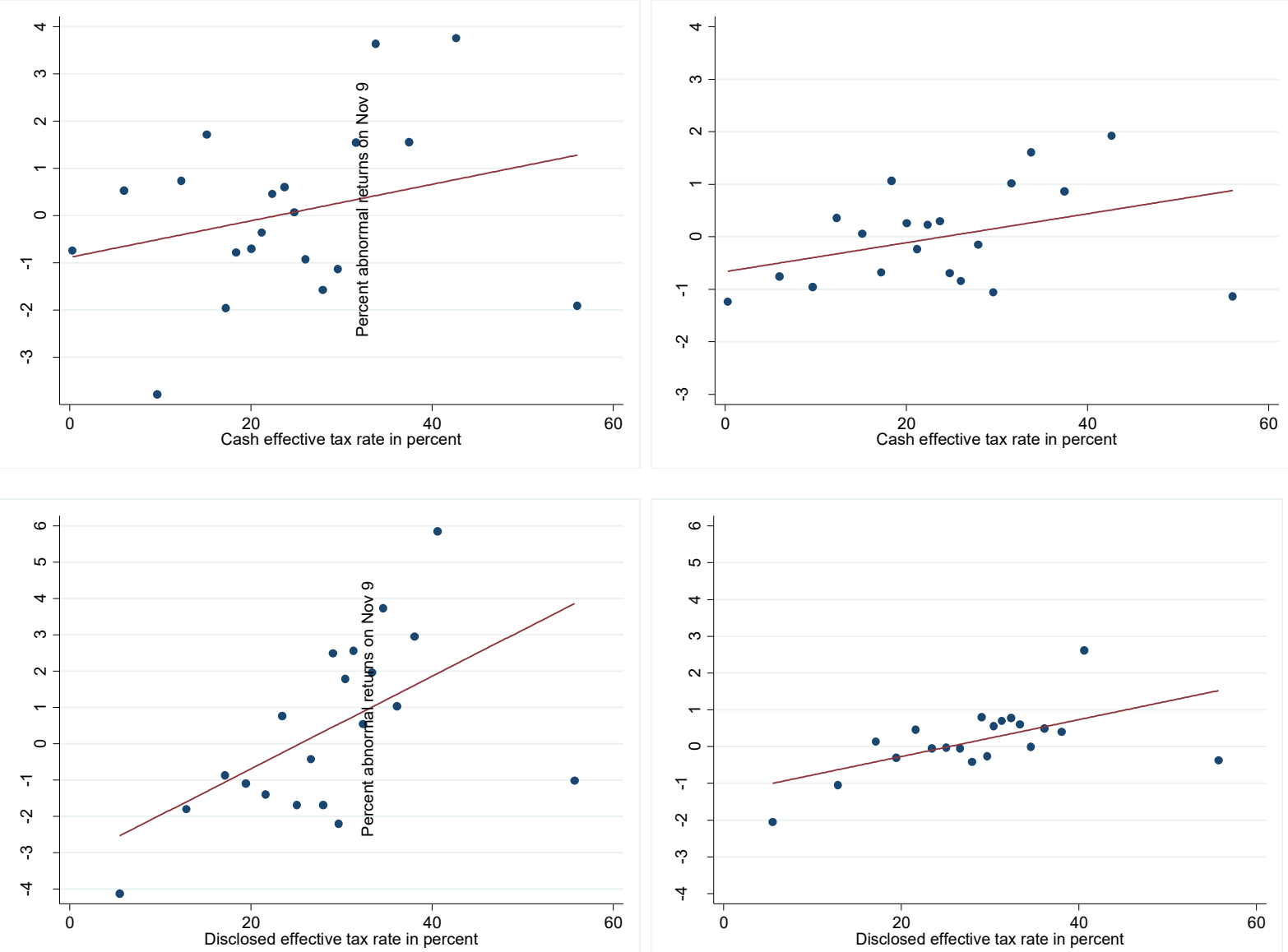

Figure 5: Binned scatter plots of Cash effective tax rate (top two panels) and Disclosed effective tax rate (bottom two panels) against abnormal returns from November 9 to December 31, 2016 (left panels) and abnormal returns on November 9, 2016 (right panels) (controlling for Fama-French 30 industries fixed effects)

\subsection{Foreign operations}

It is not clear a priori whether stocks oriented towards the US economy will fare better or worse than those that are more exposed to the world economy.

On the one hand, there are several arguments favoring stocks with a domestic focus. First, market participants may simply have higher expectations for US growth versus foreign growth. Second, stocks active abroad are more subject to the risk of trade wars that bring retaliation by other countries. In either case, firms with larger foreign presence would do worse. (Without further evidence, one cannot distinguish between the two explanations.) Third, Trump's infrastructure plan would naturally benefit domestically-focused firms. Fourth, Trump's 
expansionist fiscal policies and the associated increase in inflation expectations are likely to foster Fed rate hikes. In a number of speeches following the election, Federal Reserve officials made no secret that they might tighten policy faster if fiscal policy became more expansionary. ${ }^{12}$ While higher inflation per se would hurt the dollar in the long-run, the rate hikes could initially strengthen it, hurting exporters. Indeed, the ICE US Dollar index appreciated by $4.44 \%$ between November 8 and year-end, while the expected path of the Federal Funds rate implied from Fed Fund futures prices steepened. ${ }^{13}$ According to the minutes of the December 2016 FOMC meeting, "[s]urveys of market participants had indicated that revised expectations for government spending and tax policy following the U.S. elections in early November were seen as the most important reasons, among several factors, for the increase in longer-term Treasury yields, the climb in equity valuations, and the rise in the dollar." At that same meeting, the median of FOMC participants' projections for GDP growth rose, but only slightly. Furthermore, "[t]hose increasing their projections for output growth in those years cited expected changes in fiscal, regulatory, or other policies as factors contributing to their revisions. However, many participants noted that the effects on the economy of such policy changes, if implemented, would likely be partially offset by tighter financial conditions, including higher longer-term interest rates and a strengthening of the dollar."

On the other hand, the House Republicans' tax plan (Republicans 2016) has been interpreted to help make US companies more competitive abroad. If so, that would (relatively) favor internationally-oriented stocks. While the exact implementation is not known to date, the basic gist of the plan is that US companies would not pay tax on profits earned on overseas sales anymore. Conversely, products, services and intangibles that are imported will be subject to US tax regardless of where they are produced. ${ }^{14}$ (See Tax Foundation (2016) for a description of the plan.) The Tax Foundation, however, dismisses the argument that exporters would benefit from the plan. They write: "Of course, U.S. producers may think of this as a subsidy for exports

\footnotetext{
${ }^{12}$ The minutes of the December 2016 FOMC meeting, which were released on January 4, 2017, are in line with these statements made by Fed officials before year-end. The minutes state: «Many participants noted that there was currently substantial uncertainty about the size, composition, and timing of prospective fiscal policy changes, but they also commented that a more expansionary fiscal policy might raise aggregate demand above sustainable levels, potentially necessitating somewhat tighter monetary policy than currently anticipated.»

${ }^{13}$ On November 8, futures markets viewed the most likely range of the Fed Funds target rate following the December 2017 FOMC meeting to be $0.5-0.75 \%$ or $0.75 \%-1 \%$ (with both outcomes about equally likely). At the end of the year, the most likely range according to futures prices was $1-1.25 \%$.

${ }^{14}$ Another aspect of tax policy is the tax treatment of profits made by US firms' foreign subsidiaries. We consider this aspect at the end of this section.
} 
because they would not be taxed on sales overseas. But if businesses were able to reduce the prices of their goods they sell overseas due to the border adjustment, this would trigger a higher demand for dollars in order to purchase those goods. This higher demand for dollars would increase the value of the dollar relative to foreign currencies and offset any perceived trade advantage granted by the border adjustment." In line with this view, some market observers have claimed that (expectations of) the plan's enactment would lead to a strong appreciation of the dollar. Since some version of the plan appears likely to succeed, this raises the question why the dollar has not appreciated more strongly during the period.

Summarizing, the proposed policies could have both advantages and disadvantages for exporters and firms with significant foreign operations, and it is not obvious which would predominate. ${ }^{15}$ But investors through the stock market did take a view. Table 4 and Figure 6 suggest that investors strongly believed that domestically-oriented companies would have a relative advantage: abnormal returns are significantly negatively related to the fraction of revenues being earned outside the US. Interestingly, the negative relationship between foreign revenue and stock returns was strong not only on the day following the election, but persisted into year-end. A potential explanation is that two effects underlie the observed returns. The first - faster US GDP growth - was recognized early on by markets, while the second - negative spillover effects from more restrictive trade policies - needed some time to be incorporated into prices.

It is worth noting that the effects in Table 4 are quantitatively important. For example, a one standard deviation increase in the fraction of foreign revenues is associated with a 0.96 percentage point lower first-day return, a quarter of a standard deviation of these returns, and with a 2.15 percentage point lower cumulative abnormal return until year-end, again around a quarter of a standard deviation of these returns.

\footnotetext{
${ }^{15}$ Analysts tend to see advantages for domestic stocks. For example, in a note released on November 9, 2016 (and reported on zerohedge.com), Goldman Sachs chief strategist David Kostin argued that domestic stocks will do better than foreign-exposed stocks (Kostin 2016).
} 

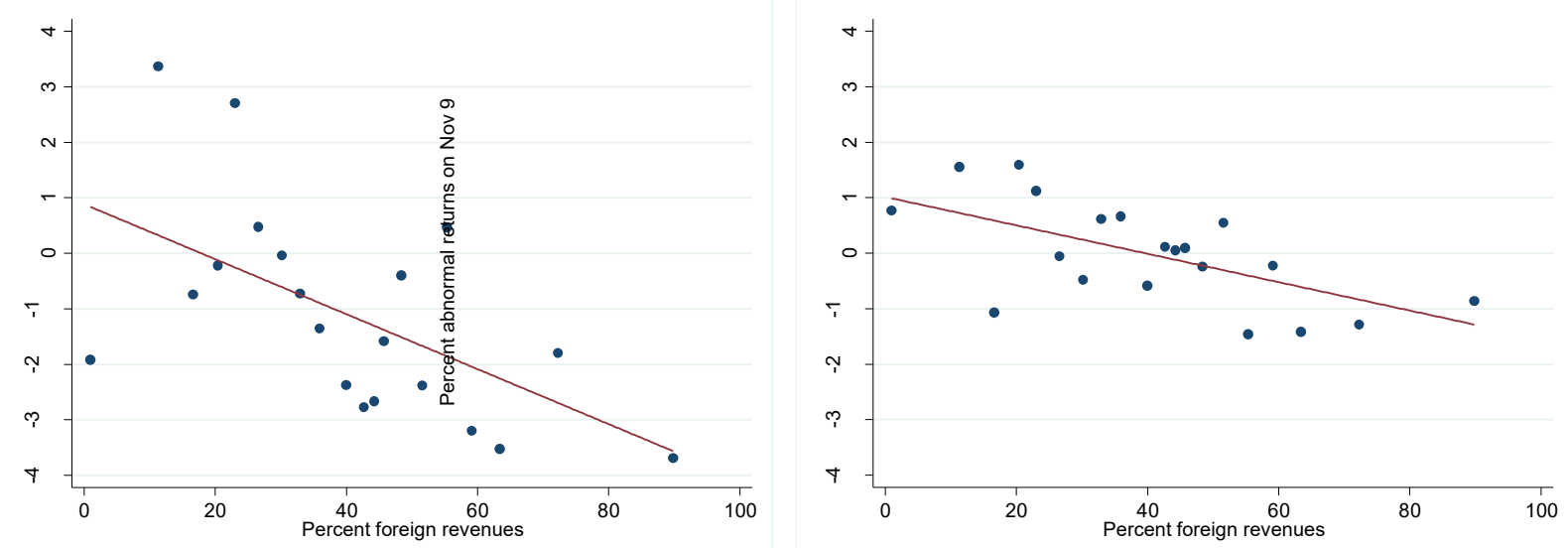

Figure 6: Binned scatter plot of Percent foreign revenues against abnormal returns from November 9 to December 31, 2016 (left panel) and abnormal returns on November 9, 2016 (right panel)

(controlling for Fama-French 30 industries fixed effects)

Table 4: Foreign operations, part 1

This table presents OLS regressions of the abnormal returns from November 9, 2016 to December 31, 2016 (column (1)), on November 9, 2016 (column (2)), and from November 10, 2016 to December 31, 2016 (column (3)) on firm characteristics and Fama-French 30 industry fixed effects. T-statistics based on robust standard errors are shown in parentheses. ${ }^{* * *} \mathrm{p}<0.01$, $* * \mathrm{p}<0.05, * \mathrm{p}<0.1$

\begin{tabular}{lccc}
\hline & $(1)$ & $(2)$ & $(3)$ \\
Dependent variable: & CAR Nov 9 to & & CAR Nov 10 to \\
Percent revenue from foreign sources & Dec 31 & AR Nov 9 & Dec 31 \\
\hline & $-0.081^{* * *}$ & $-0.036^{* * *}$ & $-0.045^{* *}$ \\
Cash taxes paid in percent of pretax income & $(-3.38)$ & $(-4.28)$ & $(-2.10)$ \\
& 0.012 & $0.039^{* *}$ & -0.025 \\
Ln(Market value of equity) & $(0.31)$ & $(2.39)$ & $(-0.71)$ \\
& 0.115 & $0.531^{* * *}$ & -0.399 \\
Beta & $(0.24)$ & $(3.17)$ & $(-0.94)$ \\
& $3.880^{* *}$ & $3.177^{* * *}$ & 0.641 \\
Percent revenue growth & $(2.16)$ & $(4.48)$ & $(0.40)$ \\
& $-0.087^{* *}$ & $-0.062^{* * *}$ & -0.026 \\
Profitability & $-2.31)$ & $(-3.15)$ & $(-0.84)$ \\
& -0.020 & 0.013 & -0.032 \\
Constant & $(-0.30)$ & $(0.52)$ & $(-0.52)$ \\
& -3.125 & $-8.430^{* * *}$ & 5.131 \\
Industry FE & $(-0.64)$ & $(-4.41)$ & $(1.14)$ \\
Observations & Yes & Yes & Yes \\
R-squared & 354 & 354 & 354 \\
\hline
\end{tabular}




\section{Table 5: Foreign operations, part 2}

This table presents OLS regressions of the abnormal returns from November 9, 2016 to December 31, 2016 (column (1)), on November 9, 2016 (column (2)), and from November 10, 2016 to December 31, 2016 (column (3)) on firm characteristics and Fama-French 30 industry fixed effects. T-statistics based on robust standard errors are shown in parentheses. $* * * p<0.01$, ** $\mathrm{p}<0.05, * \mathrm{p}<0.1$

\begin{tabular}{|c|c|c|c|}
\hline Dependent variable: & $\begin{array}{c}\text { (1) } \\
\text { CAR Nov } 9 \text { to } \\
\text { Dec } 31\end{array}$ & $\begin{array}{c}\text { (2) } \\
\text { AR Nov } 9 \\
\end{array}$ & $\begin{array}{c}\text { (3) } \\
\text { CAR Nov } 10 \text { to } \\
\text { Dec } 31\end{array}$ \\
\hline \multicolumn{4}{|l|}{ Panel A } \\
\hline Percent profits from foreign activities & $\begin{array}{c}-0.044^{* * *} \\
(-2.64)\end{array}$ & $\begin{array}{c}-0.012^{*} \\
(-1.72)\end{array}$ & $\begin{array}{c}-0.032^{* *} \\
(-2.24)\end{array}$ \\
\hline Cash taxes paid in percent of pretax income & $\begin{array}{l}0.042 \\
(0.89)\end{array}$ & $\begin{array}{c}0.032 * \\
(1.89)\end{array}$ & $\begin{array}{l}0.011 \\
(0.27)\end{array}$ \\
\hline Observations & 283 & 283 & 283 \\
\hline R-squared & 0.228 & 0.282 & 0.195 \\
\hline \multicolumn{4}{|l|}{ Panel B } \\
\hline Foreign operations in percent of assets & $\begin{array}{c}-0.497^{* * *} \\
(-3.45)\end{array}$ & $\begin{array}{c}-0.138 * * \\
(-2.09)\end{array}$ & $\begin{array}{c}-0.363^{* * *} \\
(-3.00)\end{array}$ \\
\hline Cash taxes paid in percent of pretax income & $\begin{array}{l}0.022 \\
(0.49)\end{array}$ & $\begin{array}{l}0.025 \\
(1.54)\end{array}$ & $\begin{array}{l}-0.003 \\
(-0.07)\end{array}$ \\
\hline Observations & 310 & 310 & 310 \\
\hline $\begin{array}{l}\text { R-squared } \\
\text { Panel C }\end{array}$ & 0.231 & 0.291 & 0.212 \\
\hline Percent foreign assets & $\begin{array}{l}-0.009 \\
(-0.37)\end{array}$ & $\begin{array}{l}-0.003 \\
(-0.36)\end{array}$ & $\begin{array}{l}-0.005 \\
(-0.20)\end{array}$ \\
\hline Cash taxes paid in percent of pretax income & $\begin{array}{l}-0.023 \\
(-0.37)\end{array}$ & $\begin{array}{c}0.047^{* *} \\
(2.35)\end{array}$ & $\begin{array}{l}-0.066 \\
(-1.09)\end{array}$ \\
\hline Observations & 188 & 188 & 188 \\
\hline $\begin{array}{l}\text { R-squared } \\
\text { Panel D }\end{array}$ & 0.231 & 0.433 & 0.242 \\
\hline Indefinitely reinvested foreign earnings in percent of assets & $\begin{array}{c}-6.702 * * \\
(-2.28)\end{array}$ & $\begin{array}{c}-2.622^{* *} \\
(-1.99)\end{array}$ & $\begin{array}{l}-4.039 \\
(-1.53)\end{array}$ \\
\hline Cash taxes paid in percent of pretax income & $\begin{array}{l}0.015 \\
(0.31)\end{array}$ & $\begin{array}{l}0.019 \\
(0.99)\end{array}$ & $\begin{array}{l}-0.000 \\
(-0.00)\end{array}$ \\
\hline Observations & 434 & 434 & 434 \\
\hline R-squared & 0.228 & 0.301 & 0.214 \\
\hline \multicolumn{4}{|l|}{ All panels } \\
\hline Constant & Yes & Yes & Yes \\
\hline Control variables (Size, beta, sales growth, profitability) & Yes & Yes & Yes \\
\hline Industry FE & Yes & Yes & Yes \\
\hline
\end{tabular}


We find similar results for other measures of foreign operations, reported more briefly in Table 5; the regressions include the same control variables as before, but these are not shown to save space. The share of profits due to foreign operations (Panel A) and the degree of foreign activity (Panel B) are both strongly negatively related to firms' stock market performance. Interestingly, although some observers argued that importers would suffer from the new administration's tax plan, the fraction of non-US assets is not significantly related to stock returns; see Panel C. We caution that the sample is relatively small for the latter analysis. Also, while foreign assets arguably proxy well for foreign production costs, such foreign production might not lead to imports, and conversely companies may import significant amounts of goods without owning production assets abroad. ${ }^{16}$

Another much-discussed policy issue at the intersection of foreign operations and taxes is the issue of repatriation of past earnings. Many commentators - on both sides of the political spectrum - have worried about the tendency of US companies to "stash cash abroad". The reason for this behavior lies in current tax rules. Under the current tax regime, firms are taxed on worldwide income but that tax can, with some exceptions (typically for passive income such as interest and royalties), be deferred until the foreign subsidiaries distribute the monies back to their US parent. When repatriating foreign profits, firms get a credit for the foreign taxes paid on that income. In spite of the credit, firms have been reluctant to repatriate earnings earned by foreign subsidiaries because the US corporate tax rate is much higher than the tax rate in most countries, with the consequence that credits brought in with the distribution are lower than the incremental US tax before credits.

If there were some type of tax holiday allowing companies to pay a much lower rate when repatriating foreign earnings, investors might expect companies with cash stashed abroad to do better. In fact, this expectation is mirrored in the fact that Goldman Sachs has, several years ago, compiled a thematic basket, GSTHSEAS, containing the 50 companies among the S\&P 500 with the largest cash positions held in foreign subsidiaries. Importantly, however, it is not clear whether the election would have affected companies differentially in this respect. After all, a partial tax holiday was widely expected to occur as well if Hillary Clinton had been elected

\footnotetext{
${ }^{16}$ While Table 5 only reports the results including industry fixed effects for space reasons, we have also conducted the analysis without industry fixed effects, and the results are very similar.
} 
President. ${ }^{17}$ Accordingly, the market reaction to the election on that count would be driven not so much by the enactment of a tax holiday as such, but by the perceived difference in the holiday tax rate between the two candidates, with Trump likely to favor a lower rate than Clinton. Panel $\mathrm{D}$ of Table 5 shows, however, that companies with large cash holdings in foreign subsidiaries in fact responded worse to the Trump election. When controlling for foreign revenues (not shown), the effect is insignificant, suggesting that foreign cash holdings at least partly proxy for a firm's foreign activities overall.

Recall that we found above that companies with a lot of business abroad - which are more likely to be the ones holding cash abroad - actually responded worse to Trump's election. Thus, if the repatriation tax holiday is implicitly at play in the market's expectations, something else must be particularly bad for firms with foreign activities.

\subsection{Interest expense deductibility and capital investment expensing}

Another approach that has been proposed to make the US more competitive is to strengthen firms' incentives to invest. Specifically, under the House Republicans' tax plan, businesses would no longer need to depreciate capital investments. Instead, they will be able to expense them fully in the period that they are made. Thus, firms would be able to defer corporate income taxes, which should have a positive effect on stock prices, with a larger effect for firms making greater capital expenditures relative to their size. In order to avoid a tax subsidy for debtfinanced investment, the House Republicans' plan would no longer allow net interest expenses to be deducted. This would hurt those firms with more leverage (which generates value through the tax shield in place up to now) and those with greater proportional interest expenses.

Columns (1), (3), and (5) of Table 6 reveal a negative but insignificant relationship between firm leverage and abnormal returns in the full specification. ${ }^{18}$ However, firms with substantial interest expenses reacted more negatively, as seen in column (2) of Table 6, though the reaction did not come immediately after the election (columns (4) and (6)). This result is illustrated in the top panel of Figure 7. We note that this result does not necessarily have to do

\footnotetext{
17 A different, but related question is what companies would do with the repatriated cash. Despite explicit prohibitions against the use of repatriated cash for repurchases, it appears that this is exactly what companies did use this cash for after the 2004 tax holiday (Dharmapala, Foley and Forbes 2011). Thus, an indirect effect leading to differential stock market reactions to repatriation could be due to differences in firms' financial constraints.

${ }^{18}$ The correlation between leverage and beta in our sample is slightly negative but statistically insignificant. There is no significant relationship between abnormal returns and leverage even if we do not control for beta. However, there is a negative relationship between leverage and abnormal returns when not controlling for foreign revenues.
} 
with an expectation regarding interest deductibility being abolished, as deductions also lose value when taxes are slashed (as the market seems to expect, see Section 5.2).

Table 6: Interest expense deductibility and expensing of capital expenditures

This table presents OLS regressions of the abnormal returns from November 9, 2016 to December 31, 2016 (columns (1) and (2)), on November 9, 2016 (columns (3) and (4)), and from November 10, 2016 to December 31, 2016 (columns (5) and (6)) on firm characteristics and Fama-French 30 industry fixed effects. T-statistics based on robust standard errors are shown in parentheses. $* * * \mathrm{p}<0.01, * * \mathrm{p}<0.05, * \mathrm{p}<0.1$

\begin{tabular}{lcccccc} 
& $(1)$ & $(2)$ & $(3)$ & $(4)$ & $(5)$ & $(6)$ \\
Dependent variable: & CAR Nov 9 to Dec 31 & AR Nov 9 & CAR Nov 10 to Dec 31 \\
\hline Leverage & -2.152 & & -0.565 & & -1.461 & \\
& $(-0.69)$ & & $(-0.49)$ & & $(-0.54)$ & \\
Interest expenses in percent of assets & & $-1.492^{* *}$ & & -0.212 & & $-1.246^{* *}$ \\
& & $(-2.28)$ & & $(-0.72)$ & & $(-2.33)$ \\
Capital expenditures in percent of assets & 0.033 & 0.131 & -0.023 & 0.001 & 0.036 & 0.109 \\
& $(0.15)$ & $(0.55)$ & $(-0.25)$ & $(0.01)$ & $(0.21)$ & $(0.58)$ \\
Cash taxes paid in percent of pretax income & 0.008 & -0.021 & $0.038^{* *}$ & $0.032^{* *}$ & -0.028 & -0.051 \\
& $(0.19)$ & $(-0.52)$ & $(2.33)$ & $(1.99)$ & $(-0.77)$ & $(-1.39)$ \\
Percent revenue from foreign sources & $-0.081^{* * *}$ & $-0.077^{* * *}$ & $-0.037^{* * *}$ & $-0.036^{* * *}$ & $-0.045^{* *}$ & $-0.042^{*}$ \\
& $(-3.45)$ & $(-3.24)$ & $(-4.45)$ & $(-4.18)$ & $(-2.12)$ & $(-1.94)$ \\
Ln(Market value of equity) & 0.071 & -0.152 & $0.518^{* * *}$ & $0.553^{* * *}$ & -0.428 & $-0.679 *$ \\
& $(0.15)$ & $(-0.33)$ & $(3.04)$ & $(2.93)$ & $(-0.98)$ & $(-1.68)$ \\
Beta & $3.808^{* *}$ & $3.339^{*}$ & $3.189^{* * *}$ & $3.181^{* * *}$ & 0.578 & 0.146 \\
& $(2.12)$ & $(1.83)$ & $(4.62)$ & $(4.24)$ & $(0.36)$ & $(0.09)$ \\
Revenue growth rate & $-0.089^{* *}$ & $-0.090^{* *}$ & $-0.063^{* * *}$ & $-0.063^{* * *}$ & -0.026 & -0.028 \\
& $(-2.34)$ & $(-2.41)$ & $(-3.15)$ & $(-3.18)$ & $(-0.86)$ & $(-0.92)$ \\
Profitability & -0.029 & -0.089 & 0.012 & -0.002 & -0.038 & -0.084 \\
& $(-0.43)$ & $(-1.51)$ & $(0.47)$ & $(-0.08)$ & $(-0.64)$ & $(-1.62)$ \\
Constant & -1.851 & 2.602 & $-8.007^{* * *}$ & $-8.152^{* * *}$ & 5.957 & $10.469^{* *}$ \\
& $(-0.34)$ & $(0.48)$ & $(-3.83)$ & $(-3.50)$ & $(1.19)$ & $(2.21)$ \\
Industry FE & Yes & Yes & Yes & Yes & Yes & Yes \\
Observations & 354 & 343 & 354 & 343 & 354 & 343 \\
R-squared & 0.249 & 0.261 & 0.332 & 0.336 & 0.230 & 0.244 \\
\hline
\end{tabular}

We find no significant relationship between immediate or long-run abnormal returns and CAPEX, as can also be seen by the virtually flat regression lines in the bottom panel of Figure 8 . (We control for leverage or interest expenses in these regressions, as any benefit from immediate expensing would be offset from the non-deductibility of interest, assuming the investments would have been financed with bonds, but the same result holds when not controlling for these 
variables.) Thus, investors seemed to believe that either the Republicans' proposed capital expenditure rule is unlikely to have large effects, or that it is unlikely to be implemented. ${ }^{19}$
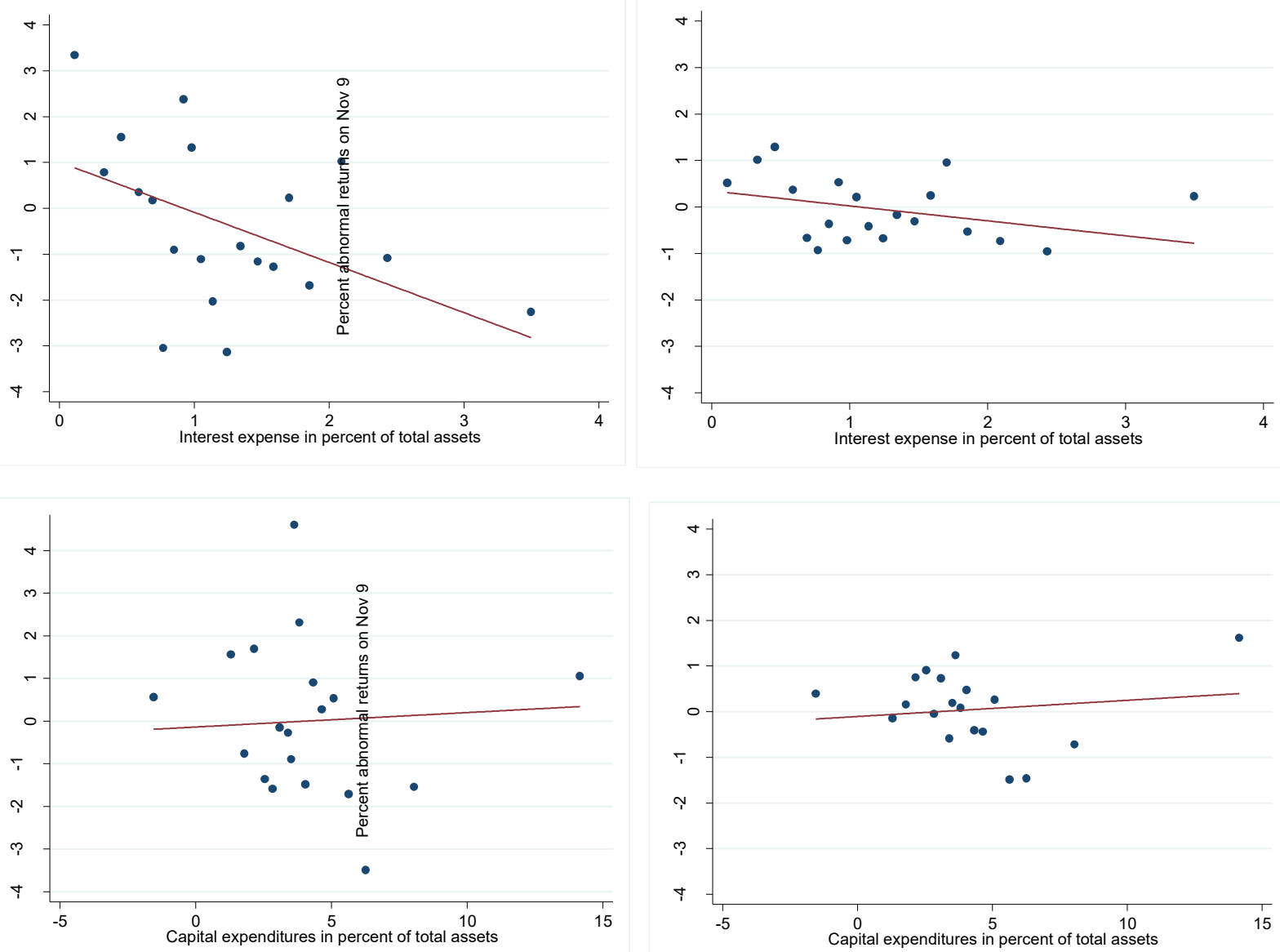

Figure 7: Binned scatter plots of Interest expense in percent of assets (top two panels) and Capital expenditures in percent of assets (bottom two panels) against abnormal returns from November 9 to December 31, 2016 (left panels) and abnormal returns on November 9, 2016 (right panels)

(controlling for Fama-French 30 industries fixed effects)

\footnotetext{
${ }^{19}$ While the House Republicans' plan removes interest deductibility for all firms and allows all firms to expense capital investments, Trump's plan, as described on https:/www.donaldjtrump.com/policies/tax-plan/ (visited on February 1, 2017), is to restrict the possibility to expense capital investment to manufacturers. These companies would be allowed to opt (once in three years) to expense, but would then give up the interest deduction. When restricting the sample to the 165 firms in SIC codes 2000 to 3999 (manufacturing), the coefficient on capital expenditures is positive in regressions like those in Table 6 , but still below conventional significance levels.
} 


\subsection{Extreme returns}

A potential concern regarding the analysis so far is that extreme returns might confound our inferences. We now briefly present summary results for our key findings when adjusting outlier returns. Panel A of Table 7 shows results when abnormal returns are winsorized at the $1 \%$ and 99\% levels, and Panel B trims the observations with the 1\% highest and lowest returns. Virtually the same findings as before emerge, though often with higher statistical significance: Taxes and growth expectations were already reflected in stock prices on the day after the election, while foreign revenues and interest expenses took longer to have an effect.

\section{Table 7: Extreme returns}

This table presents OLS regressions of the abnormal returns from November 9, 2016 to December 31, 2016 (columns (1) and (2)), on November 9, 2016 (columns (3) and (4)), and from November 10, 2016 to December 31, 2016 (columns (5) and (6)) on firm characteristics and Fama-French 30 industry fixed effects. In Panel A, abnormal returns are winsorized at the $1 \%$ and $99 \%$ levels. In Panel B, abnormal returns are trimmed at the 1\% and 99\% level. T-statistics based on robust standard errors are shown in parentheses. ${ }^{* * *} \mathrm{p}<0.01,{ }^{* *} \mathrm{p}<0.05,{ }^{*} \mathrm{p}<0.1$

\begin{tabular}{|c|c|c|c|c|c|c|}
\hline \multirow{2}{*}{\multicolumn{7}{|c|}{$\begin{array}{c}(1) \\
\text { Panel A: Abnormal returns winsorized at the } 1 \% \text { and } 99 \% \text { level }\end{array}$}} \\
\hline & & & & & & \\
\hline \multirow{3}{*}{$\begin{array}{l}\text { Dependent variable: } \\
\text { Cash taxes paid in percent of pretax income }\end{array}$} & \multicolumn{2}{|c|}{ CAR Nov 9 to Dec 31} & \multicolumn{2}{|c|}{ AR Nov 9} & \multicolumn{2}{|c|}{ CAR Nov 10 to Dec 31} \\
\hline & 0.019 & -0.012 & $0.028^{* *}$ & $0.036 * * *$ & 0.006 & -0.032 \\
\hline & $(0.54)$ & $(-0.34)$ & $(2.17)$ & $(2.65)$ & $(0.21)$ & $(-1.08)$ \\
\hline Percent revenue from foreign sources & & $\begin{array}{c}-0.083 * * * \\
(-4.01)\end{array}$ & & $\begin{array}{c}-0.035 * * * \\
(-4.34)\end{array}$ & & $\begin{array}{c}-0.053 * * * \\
(-3.03)\end{array}$ \\
\hline Interest expense in percent of assets & $\begin{array}{c}-1.721 * * * \\
(-3.21)\end{array}$ & $\begin{array}{c}-1.594 * * * \\
(-2.64)\end{array}$ & $\begin{array}{c}-0.596 * * \\
(-2.40)\end{array}$ & $\begin{array}{l}-0.342 \\
(-1.34)\end{array}$ & $\begin{array}{c}-0.991 * * \\
(-2.15)\end{array}$ & $\begin{array}{c}-1.151^{* *} \\
(-2.39)\end{array}$ \\
\hline Capital expenditures in percent of assets & $\begin{array}{l}0.038 \\
(0.19)\end{array}$ & $\begin{array}{l}0.128 \\
(0.57)\end{array}$ & $\begin{array}{l}0.034 \\
(0.44)\end{array}$ & $\begin{array}{l}0.005 \\
(0.07)\end{array}$ & $\begin{array}{l}0.003 \\
(0.02)\end{array}$ & $\begin{array}{l}0.111 \\
(0.61)\end{array}$ \\
\hline Ln(Market value of equity) & $\begin{array}{l}-0.648 \\
(-1.64)\end{array}$ & $\begin{array}{l}-0.092 \\
(-0.22)\end{array}$ & $\begin{array}{l}0.145 \\
(0.92)\end{array}$ & $\begin{array}{c}0.458^{* * *} \\
(2.78)\end{array}$ & $\begin{array}{c}-0.777^{* *} \\
(-2.31)\end{array}$ & $\begin{array}{l}-0.546 \\
(-1.51)\end{array}$ \\
\hline Beta & $\begin{array}{l}1.751 \\
(1.26)\end{array}$ & $\begin{array}{l}3.016^{*} \\
(1.75)\end{array}$ & $\begin{array}{c}2.558^{* * *} \\
(4.22)\end{array}$ & $\begin{array}{c}3.039 * * * \\
(4.44)\end{array}$ & $\begin{array}{l}-0.908 \\
(-0.73)\end{array}$ & $\begin{array}{l}0.015 \\
(0.01)\end{array}$ \\
\hline Percent revenue growth & $\begin{array}{c}-0.090 * * * \\
(-3.09)\end{array}$ & $\begin{array}{c}-0.095 * * * \\
(-2.75)\end{array}$ & $\begin{array}{c}-0.042 * * * \\
(-3.09)\end{array}$ & $\begin{array}{c}-0.053^{* * *} \\
(-3.71)\end{array}$ & $\begin{array}{l}-0.044^{*} \\
(-1.84)\end{array}$ & $\begin{array}{l}-0.040 \\
(-1.48)\end{array}$ \\
\hline Profitability & $\begin{array}{c}-0.104 * \\
(-1.74)\end{array}$ & $\begin{array}{l}-0.084 \\
(-1.47)\end{array}$ & $\begin{array}{l}-0.016 \\
(-0.60)\end{array}$ & $\begin{array}{l}0.001 \\
(0.02)\end{array}$ & $\begin{array}{l}-0.082 \\
(-1.63)\end{array}$ & $\begin{array}{l}-0.079 \\
(-1.58)\end{array}$ \\
\hline Constant & $\begin{array}{l}6.843 \\
(1.45)\end{array}$ & $\begin{array}{l}2.388 \\
(0.47)\end{array}$ & $\begin{array}{c}-4.008^{* *} \\
(-1.99)\end{array}$ & $\begin{array}{c}-7.017^{* * *} \\
(-3.40)\end{array}$ & $\begin{array}{c}10.223^{* *} \\
(2.51)\end{array}$ & $\begin{array}{c}8.960^{* *} \\
(2.06)\end{array}$ \\
\hline Industry FE & Yes & Yes & Yes & Yes & Yes & Yes \\
\hline Observations & 413 & 343 & 413 & 343 & 413 & 343 \\
\hline R-squared & 0.247 & 0.288 & 0.355 & 0.385 & 0.236 & 0.276 \\
\hline
\end{tabular}

[continued on next page] 
Table 7: Extreme returns [continued from previous page]

\begin{tabular}{|c|c|c|c|c|c|c|}
\hline & (1) & (2) & (3) & (4) & (5) & (6) \\
\hline \multicolumn{7}{|c|}{ Panel B: Abnormal returns trimmed at the $1 \%$ and $99 \%$ level } \\
\hline Dependent variable: & \multicolumn{2}{|c|}{ CAR Nov 9 to Dec 31} & \multicolumn{2}{|c|}{ AR Nov 9} & \multicolumn{2}{|c|}{ CAR Nov 10 to Dec 31} \\
\hline \multirow[t]{2}{*}{ Cash taxes paid in percent of pretax income } & 0.040 & 0.020 & $0.033^{* * *}$ & $0.037^{* * *}$ & 0.023 & -0.004 \\
\hline & $(1.20)$ & $(0.58)$ & $(2.67)$ & $(2.85)$ & $(0.86)$ & $(-0.17)$ \\
\hline \multirow[t]{2}{*}{ Percent revenue from foreign sources } & & $-0.096 * * *$ & & $-0.034 * * *$ & & $-0.065 * * *$ \\
\hline & & $(-5.55)$ & & $(-4.31)$ & & $(-4.26)$ \\
\hline \multirow[t]{2}{*}{ Interest expense in percent of assets } & $-2.035 * * *$ & $-1.963 * * *$ & $-0.586 * * *$ & $-0.500 * *$ & $-0.718^{*}$ & $-0.749^{*}$ \\
\hline & $(-4.57)$ & $(-3.87)$ & $(-2.97)$ & $(-2.18)$ & $(-1.69)$ & $(-1.77)$ \\
\hline \multirow[t]{2}{*}{ Capital expenditures in percent of assets } & -0.024 & 0.063 & -0.014 & -0.014 & 0.077 & 0.191 \\
\hline & $(-0.14)$ & $(0.33)$ & $(-0.22)$ & $(-0.21)$ & $(0.52)$ & $(1.14)$ \\
\hline \multirow[t]{2}{*}{ Ln(Market value of equity) } & $-0.684^{*}$ & -0.042 & 0.120 & $0.372 * *$ & $-0.694 * *$ & -0.348 \\
\hline & $(-1.84)$ & $(-0.11)$ & $(0.82)$ & $(2.35)$ & $(-2.19)$ & $(-1.07)$ \\
\hline \multirow[t]{2}{*}{ Beta } & 0.587 & 1.567 & $1.909 * * *$ & $2.527^{* * *}$ & -1.752 & -1.056 \\
\hline & $(0.47)$ & $(1.06)$ & (3.51) & $(4.08)$ & $(-1.55)$ & $(-0.80)$ \\
\hline \multirow{2}{*}{ Percent revenue growth } & $-0.087^{* * *}$ & $-0.094 * * *$ & $-0.039 * * *$ & $-0.042 * * *$ & $-0.065^{* * *}$ & $-0.068 * *$ \\
\hline & $(-3.34)$ & $(-3.20)$ & $(-3.44)$ & $(-3.40)$ & $(-2.77)$ & $(-2.57)$ \\
\hline \multirow[t]{2}{*}{ Profitability } & -0.083 & -0.054 & -0.023 & -0.006 & $-0.082^{*}$ & -0.073 \\
\hline & $(-1.44)$ & $(-1.01)$ & $(-0.93)$ & $(-0.23)$ & $(-1.70)$ & $(-1.53)$ \\
\hline \multirow[t]{2}{*}{ Constant } & $8.257^{*}$ & 3.350 & $-3.003^{*}$ & $-5.355^{* * *}$ & $9.238 * *$ & $6.980 *$ \\
\hline & $(1.85)$ & $(0.73)$ & $(-1.66)$ & $(-2.75)$ & $(2.37)$ & $(1.73)$ \\
\hline Industry FE & Yes & Yes & Yes & Yes & Yes & Yes \\
\hline Observations & 405 & 335 & 403 & 337 & 406 & 336 \\
\hline R-squared & 0.274 & 0.336 & 0.365 & 0.398 & 0.266 & 0.325 \\
\hline
\end{tabular}

\section{Conclusion}

The election of Donald J. Trump as the $45^{\text {th }}$ President of the United States of America surprised the nation and its investors. As expected, company stock reactions to the election reflect expected benefits and costs for shareholders. Investors clearly expect US corporate taxes to be cut (resulting in relative advantages for companies that had so far been paying high taxes). They worry substantially about US companies with significant non-US revenues. And they so far seem to think that changes in plans regarding the deductibility of capital expenses are either not likely to be implemented, or that they will not, in fact, benefit companies that need to make such investments. Overall, our results suggest that while investors incorporated the expected consequences of the election for US growth and tax policy into prices relatively quickly, it took them more time to digest the consequences of shifts in trade policy on firms' prospects. Alternatively, statements by the incoming administration or members of Congress in the postelection period provided the market with new information, implying that internationally-oriented firms were likely to suffer differentially. 
Besides a study of stock market reactions, this election is likely to spur additional work exploiting this shock in the study of empirical corporate finance topics. Whenever researchers need an unanticipated change of expectations regarding future taxes, for example, the Trump victory should prove useful.

It is important to caution the reader that substantial new information will unfold as the Trump Presidency progresses. Important elements of the short-term expectations about policies and their effects on company fortunes, whether for the day beyond or the seven weeks beyond Election Day, may well reverse themselves when policies are actually implemented. Whatever one's politics, the initial days of the Trump Presidency lend confidence to one prediction: significant policy surprises, and significant changes in company stock prices, lurk in the nearand not-so-near term future. 


\section{References}

Dharmapala, D., Foley, C.F., and Forbes, K.J., 2011. Watch What I do, Not What I Say: The Unintended Consequences of the Homeland Investment Act. The Journal of Finance 66, 753-787

Dyreng, S.D., Hanlon, M., Maydew, E.L., and Thornock, J.R., 2017. Changes in Corporate Effective Tax Rates Over the Past 25 Years. Journal of Financial Economics forthcoming

Jalan, A., Kale, J.R., and Meneghetti, C., 2016. Debt, Bankruptcy Risk, and Corporate Tax Sheltering. Working paper

Kostin, D., 2016. US equity implications of a Trump Presidency. Goldman Sachs

Manzon, G.B., and Plesko, G.A., 2002. The relation between financial and tax reporting measures of income. Tax Law Review 55, 175-214

Niederhoffer, V., Gibbs, S., and Bullock, J., 1970. Presidential Elections and the Stock Market. Financial Analysts Journal 26, 111-113

Republicans, 2016. A Better Way -- Tax Policy Paper (June 24, 2016). House Republicans, Washington, DC

Santa-Clara, P., and Valkanov, R., 2003. The Presidential Puzzle: Political Cycles and the Stock Market. The Journal of Finance 58, 1841-1872

Schwert, G.W., 1981. Using financial data to measure effects of regulation. The Journal of Law and Economics 24, 121-158

TaxFoundation, 2016. The House GOP's Destination-Based Cash Flow Tax, Explained. URL http://taxfoundation.org/blog/house-gop-s-destination-based-cash-flow-tax-explained

Wolfers, J., and Zitzewitz, E., 2016. What do financial markets think of the 2016 election? . Working paper 